\title{
Enkele ontbrekende en omstrede woorde in die Veeartsenykundige Woordeboek
}

\author{
J.F.W. Grosskopf \\ Departement Veterinêre Fisiologie, Universiteit van Pretoria, Pretoria 0002
}

Die Afrikaanse veeartsenykundige vaktaal en terminologie het hoofsaaklik op Onderstepoort, by die Navorsingsinstituut vir Veeartsenykunde en die Fakulteit Veeartsenykunde van die Universiteit van Pretoria, sy ontstaan gehad. Vanselfsprekend bestaan daar groot oorvleueling met die veekundige en geneeskundige vaktale waaruit baie van die terme ontleen is.

Weens die tweetaligheid van sowel die fakulteit as die navorsingsinstituut het die Engelse terminologie 'n baie groot invloed - soms ten goede, soms ten kwade - op die ontwikkeling van die Afrikaanse vaktaal uitgeoefen. 'n Voorbeeld hiervan is bv. die vertaling van die Engelse woord cyst (Grieks: kystos, 'n blasie gevul met vog). Snyman' stel voor dat die Griekse $k$ behou word en dat dit in Afrikaans kist moet wees, terwyl Brink ${ }^{1}$ meer geneë voel vir sist. Min Afrikaanssprekende veeartse sal weet wat met kiste en kistiese toestand bedoel word. Hulle gebruik siste en sistiese toestand. 'n Ander vertaling wat dikwels deur veeartse gebruik word, is infeksieuse (Eng: infectious) in plaas van die suiwer Afrikaanse woord besmetlike of anders selfs infektiewe' soos in infektiewe hepatitis.

Die veeartsenykundige vaktaal is nie net tot die dieregeneeskunde en -chirurgie beperk nie. Eintlik behoort ons van die veeartsenykundige wetenskappe te praat wat vakgebiede soos Anatomie, Bakteriologie, Biochemie, Diereteling en -versorging, Entomologie, Farmakologie, Fisiologie, Helmintologie, Protosoölogie, Toksikologie, Virologie en Voedingkunde insluit. Elkeen van dié vakgebiede het 'n eie terminologie wat nie noodwendig tot die veeartsenykunde beperk is nie. Die gebruike in daardie vakgebiede moet dus ook gerespekteer word.

Die Vaktaalburo het in 1978 'n tweetalige Veeartsenykundige Woordeboek gepubliseer. ${ }^{2}$ Hierdie woordeboek het in 'n lankgevoelde behoefte voorsien. Soos met alle eerste uitgawes, kom enkele omstrede vertalings egter daarin voor, en uiteraard ontbreek daar ook baie lemmas wat 'n mens graag in dié woordeboek sou wou sien. In 'n snelgroeiende wetenskap soos die veeartsenykunde het daar boonop behoefte aan baie nuwe Afrikaanse woorde sedert die eerste uitgawe van genoemde woordeboek ontstaan.

\section{ONTBREKENDE WOORDE IN DIE VEEARTSENYKUNDIGE WOORDEBOEK ${ }^{2}$}

Voorbeelde van 'n aantal woorde wat al in genoemde woordeboek gesoek is en nie gevind kon word nie, word hieronder met hulle voorgestelde Afrikaanse vertalings gelys of bespreek. Die lys is net tot enkele voorbeelde beperk. Heelparty meer woorde ontbreek, maar dié waarvan die vertaling vanselfsprekend is, is doelbewus nie ingesluit nie. 'n Aantal probleemwoorde word bespreek en voorstelle van lesers daaroor sal verwelkom word.

abstract: ekserp, uittreksel (of samevatting)

accessory sexual glands: bygeslagskliere

acidosis: asidose

alveolar ventilation: alveolêre ventilasie

cardio pulmonary flow index (CPFI): kardiopulmonale vloeiindeks

chronic obstructive pulmonary disease (COPD): chroniese obstruktiewe longsiekte

depolarization: depolarisering (van senuwees)

diastole: diastolie

diastolic pressure: diastoliese (bloed-)druk

faeces: mis (feses?)

fast twitch fibres: vinnig saamtrekkende (spier-) vesels

glycolytic pathway: glikolitiese baan

hypoxia: hipoksie

intocixation: vergiftiging

kennel: hondehok, hondeherberg, hondehotel

lung compliance: longmeegewendheid

metabolic profile: metaboliese profiel

nephron: nefron

pressure transducer: drukomskakelaar

phytobezoar: veselbol (in spysverteringskanaal)

thermistor: hittesensor (die Fisikawoordeboek gee die lemma termister)

trichobezoar (pilobezoar): haarbal, haarbol (in spysverteringskanaal)

Pant of panting is Engelse woorde waarvoor daar nog nie goeie Afrikaanse sinonieme gevind kon word nie. Pant (dyspnoea) mag asemjaging of hyg beteken wanneer 'n dier in asemnood verkeer. Pant verwys egter eintlik na 'n fisiologiese proses, sonder enige asemnood, wat deur sommige diersoorte (bv. hond, skaap en die meeste voëlsoorte) aangewend word om deur verhoogde verdamping van vog uit die asemhalingsweë doeltreffend af te koel. Panting vir afkoeling word gekenmerk deur 'n vinnige vlak asemhaling sonder verhoogde gaswisseling in die longe, maar wel 'n aansienlike verhoging in die volume lug wat per minuut deur die neus (of mond) in- en uitvloei. 'n Skaap kan byvoorbeeld sonder enige inspanning sy asemhalingstempo tot ongeveer $\mathbf{4 0 0}$ maal per minuut verhoog om af te koel.

Is asemjaging 'n geskikte Afrikaanse vertaling vir panting of nie? Hyg skep meer die indruk van asem- 
nood. Kommentaar of aanbeveling oor 'n geskikte vertaling sal verwelkom word.

Dope en doping is woorde waarvan die vertaling in die dierewêreld nie so maklik is nie. In die geval van mense is opkikkermiddels en opkikkering heeltemal aanvaarbaar, omdat dit by mense net met die oog op verbeterde fisiese prestasie gebruik word. By diere, veral in die perdewedrenbedryf, mag dit dalk (onwettiglik) vir verbeterde of vir vertraagde reaksie toegedien word. Dope kan dus of 'n opkikkermiddel of 'n vertragingsmiddel wees. Dope mag in die geneeskunde ook 'n dwelmmiddel wees (vgl. Brink').

Die woord kennel kom ook nie in die Veeartsenykundige Woordeboek ${ }^{2}$ voor nie. Die Afrikaanse vertaling is natuurlik hondehok, maar met kennel mag ook 'n hondeherberg (of dalk hondehotel), of 'n plek waar honde geteel word (hondeteelplaas) bedoel word.

Buffy coat: Dit verwys na die dun, skaars sigbare lagie witbloedselle wat bo-op die rooibloedselle dryf nadat ongestolde bloed gesentrifugeer is. Witsellagie sal waarskynlik die beste vertaling daarvoor wees.

Steaming up en flushing verwys beide na byvoeding aan diere op strategiese tye. Steaming up word hoofsaaklik by melkkoeie gebruik wanneer hulle kort voor kalwing meer gekonsentreerde voer gegee word voordat hulle in melk kom. Opbouvoeding behoort 'n aanvaarbare Afrikaanse woord daarvoor te wees.

Flushing beteken om vroulike diere voor hulle natuurlike paarseisoen op 'n hoër voedingspeil te plaas om hulle geslagsiklusse vroeër te laat begin. Dit word veral met sukses op skaapooie toegepas. Prikkelvoeding $^{2}$ is die mooi beskrywende Afrikaanse woord daarvoor.

\section{ENGELSE WOORDE MET VERKEERDE OF OMSTREDE AFRIKAANSE VERTALINGS}

'n Aantal woorde is in die Veeartsenykundige Woordeboek ${ }^{2}$ opgeneem waarmee die outeur nie volkome kan saamstem nie en ander waarvoor daar suiwerder Afrikaanse sinonieme bestaan. Daar is ook enkele verkeerde Afrikaanse ekwivalente teengekom wat reggestel behoort te word. Die volgende woorde regverdig bespreking:

anesthetic (adj): anesteties. Anesteties is seker nie verkeerd nie, maar verdowings- behoort bygevoeg te word soos in verdowingsapparaat of verdowingsmiddel.

bay: rooibruin, vos. Die woord het betrekking op die kleur van perde. Die aanvaarde vertaling vir bay is bruin of bruinperd. Sommige boere gebruik wel die woord rooibruin om te onderskei tussen bay en brown. Laasgenoemde kan in Afrikaans of bruin òf donkerbruin wees en beskryf ' $n$ byna carrying capacity: drakrag (veld).

dun: vaalbruin.

epidemiologie en episoötiologie.

hematocrit: hematokriet.

implant: inplant.

inovulation: inovulasie. swart of donkerbruinperd met bruin om die bek.

Die vertaling vos is beslis verkeerd. Die Engels vir vos is chestnut en sweetvos is liver chestnut. 'n Vosperd is 'n rooibruin of goudbruin perd met maanhare en stert met dieselfde kleur. 'n Bay is 'n rooibruin perd met swart stert- en maanhare en swart aan die bene.

Weidingkundiges verkies beweidingskapasiteit bo drakrag. Drakrag bly egter 'n mooier en eg Afrikaanse woord.

Dit is ook 'n kleur van perde. Vaalgeel sou 'n beter vertaling gewees het as vaalbruin.

Epidemiologie verwys na die voorkoms en verspreiding van menslike siektetoestande en episoötiologie na dié van dieresiektes. Die gebruik is om epidemiologie al meer ook met betrekking tot dieresiektes te gebruik. As dit aanvaarbaar is, behoort daar gestandaardiseer te word. Dieselfde is van toepassing op ensoöties en endemies.

\section{Hematocrit verteen-} woordig die gedeelte van die bloedvolume wat deur die rooiselle beslaan word. Brink' gebruik ook die vertaling hematokriet. In die veeartsenykundige wêreld word hematokrit egter alledaags gebruik, terwyl hematokriet nooit gehoor word nie. Snyman ${ }^{7}$ en Meyer ${ }^{5}$ gebruik albei hematokrit.

Volgens die Woordeboek $^{2}$ is die Afrikaanse vertaling vir implant: inplant. Waarom dan implantasie vir implantation?

Sowel die Engelse as Afrikaanse woorde is in Suid-Afrika geskep en word, sover bekend, 
nêrens elders in die wêreld gebruik nie. Dit word in die plek van embrio-oorplanting gebruik en word ook in die Wet op Veeverbetering (Wet nr. 25 van 1977) so beskryf. Inovulasie of inovulering verwys na die inplanting of oorplanting van 'n ovum. Inderdaad word geen ovum ooit oorgeplant nie, maar wel 'n bevrugte ovum wat reeds enkele seldelings ondergaan het, m.a.w. 'n embrio. Die Engelssprekende wêreld praat dan ook tereg van embryo transfer (afk. ET). Die Veeartsenykundige Woordeboek ${ }^{2}$ noem nie embryo transfer nie. Die Afrikaanse vertaling is embrio-oorplasing (EO). Embrio-inplanting of -oorplanting is verkeerd.

one-host tick:

eenherige bosluis. Dié Afrikaanse vertaling word nie algemeen gebruik nie. Tog is dit 'n goeie verkorting van die meer populêre eengasheerbos/uis.

overstock: oorbeset. Overstock mag na oorbesetting van hokke of van weiding verwys. Oorbeset is heeltemal toepaslik wanneer 'n hok of kraal betrokke is, maar in die geval van weiding behoort oorbelading of oorbeweiding as alternatiewe vertalings bygevoeg te word.

unthrifty: swakgroeiend. Unthriftiness in diere is nie net swakgroeiend nie, maar word ook gebruik om 'n algemene ongesondheidstoestand aan te dui. Kroes of kroeserig mag ook die toestand beskryf. (Wat van $k$ nies/knieserig?) In dieselfde sin word die term Off-colour ook dikwels in Engels gebruik. By mense sal dit vertaal kan word as "voel nie lekker nie", maar hoe weet ons hoe die dier voel?

\section{HORMOONBENAMINGS}

Daar bestaan nog heelparty verskille oor die benaming van hormone, veral die vrylatingshormone of vrystellingshormone (releasing hormones) wat deur die hipotalamus ('n deel van die brein) gevorm word en wat deur 'n klein poortaarstelsel na die adenohipofise vervoer word. Dié vrystellingshormone word liberiene genoem en veroorsaak elkeen die vrylating van een van die hormone wat in die adenohipofise gevorm word. Vir sommige van die hipofise se hormone is daar ook inhiberingsfaktore of statiene, afkomstig van die hipotalamus, wat die vrystelling van die betrokke hormone inhibeer.

Die hormone van die adenohipofise stimuleer op hulle beurt weer die afskeiding van ander hormone, bv. tirö̈edstimuleringshormoon. Nou vind 'n mens die belaglike name soos tiroïedstimuleringshormoonvrystellingshormoon en melanotropienvrystellingsinhiberingshormoon. ${ }^{4}$ Gelukkig is daar nou korter name, tiroliberien en melanostatien.

Die Veeartsenykundige Woordeboek ${ }^{2}$ gee die Afrikaanse vertaling van releasing hormone as losserhormoon aan. Dié woord word egter nooit gebruik nie. Al is dit 'n langer woord, word die gebruiklike vrystellingshormoon dus aanbeveel.

Daar is internasionaal besluit om die vrystellingshormone en hulle antagoniste, die inhiberingsfaktore, respektiewelik liberiene en statiene te noem. Desondanks vind die gebruik van laasgenoemde twee name min byval in die wetenskaplike literatuur, met die uitsondering van somatostatien, 'n hormoon wat die vrylating van groeihormoon (somatotropien) onderdruk, maar wat ook ander funksies het.

'n Reeks van Engelse en Afrikaanse sinonieme vir die hormone wat deur die hipotalamus en die adenohipofise afgeskei word, word in tabel 1 gegee.

Hormone wat ander endokriene kliere se funksie stimuleer, word of trofiese (trophic) of tropiese (tropic) hormone genoem. Trofies is afgelei van die Griekse trophe ${ }^{6}$ wat kos beteken en tropies van tropos $^{6}$ wat draaiing of verandering aandui. Albei vorms is aanvaarbaar, omdat so 'n hormoon 'n voedings- of 'n veranderingsfunksie in die skyforgaan teweegbring. Onder die Amerikaanse invloed het tropies al meer inslag gevind, terwyl dit ook eintlik beter by die betekenis as trofies pas. Dit word dus voorgestel dat net tropies in die toekoms in vakwoordelyste gebruik behoort te word. Dit is ook in ooreenstemming met die aanbeveling van die IUPAC-IUB se Kommissie oor Biochemiese Benamings. ${ }^{3}$

Snyman se woordeboek ${ }^{7}$ gee net -tropien aan, bv. tireotropien. Brink ${ }^{1}$ ignoreer weer -tropien en noem net thyrotrophin: tirotrofien. Brink laat dus ook die -e- uit tireoiled weg.

Tireoïed (skildklier) is afgelei van die Griekse woord vir skildvormig, thyreoeides. ${ }^{6}$ In Engels het die $e$ uit thyreoid mettertyd verdwyn om thyroid te word. Tiroïed is die algemeen aanvaarde vorm in Afrikaans. Tireoïed word in Afrikaans, onder die invloed van wyle prof. Snyman, skynbaar net deur die 
TABEL 1

Engelse en Afrikaanse sinonieme vir hormone wat deur die hipotalamus en adenohipofise afgeskei word

\section{Hormoon}

Somatoliberien

Somatostatien

Tiroliberien

Prolaktoliberien

Prolaktostatien

Kortikoliberien

Gonadoliberien

Soms verdeel in:

Folliberien

Luliberien

Melanoliberien

Melanostatien

\section{Afrikaanse sinonieme}

Groeihormoonvrystellingshormoon* (GH-VH)

Somatotropienvrystellingshormoon

Somatotropiese hormoon-vrystellingshormoon (STH-VH)

Groeihormooninhiberingshormoon** Somatotropieninhiberingshormoon Groeihormooninhibien

Tiroïedstimuleringshormoonvrystellingshormoon (TSH-VH)

Tirotropienvrystellingshormoon

Prolaktienvrystellingshormoon (P-VH)

Prolaktieninhiberingshormoon (P-IH)

Adrenokortikotropiese hormoon-vrystellingshormoon

Kortikotropienvrystellingshormoon

Gonadotropienvrystellingshormoon (Gn-VH)

Follikelstimulerende hormoon-vrystellingshormoon (FSH-VF)

Luteiniserende hormoon-vrystellingshormoon (LH-VF)

Melanosietstimuleringshormoonvrystellingshormoon (MSH-VH)

Melanotropienvrystellingshormoon

Melanosietstimuleringshormooninhiberingshormoon Melanotropieninhiberingshormoon
Engelse sinonieme

Somatoliberin

Growth hormone stimulating hormone

Somatotropin releasing hormone

Somatotropic hormone releasing hormone (STH-RH)

Somatostatin

Growth hormone inhibiting hormone

Somatotropin inhibiting hormone

Thyroliberin

Thyroid stimulating hormone releasing hormone (TSH- $\mathrm{RH}$ )

Thyrotropin releasing hormone

Prolactoliberin

Prolactin releasing hormone

Prolactostatin

Prolactin inhibiting hormone (P-IH)

Corticoliberin

Adrenocorticotropic hormone releasing hormone (ACTH-RH)

Corticotropin releasing hormone

Gonadoliberin

Gonadotropin releasing hormone (GnRH)

Follicle stimulating hormone releasing hormone (FSH-RH)

Luliberin

Luteinizing hormone releasing hormone (LH-RH)

Melanoliberin

Melanocyte stimulating hormone releasing hormone (MSH-RH)

Melanotropin releasing hormone

Melanostatin

Melanocyte stimulating hormone inhibiting hormone

Melanotropin inhibiting hormone

*Vrystellingshormone ( $\mathrm{VH})$ was tot onlangs nog bekend as vrystellingsfaktore.

** Inhiberingshormone behoort na regte vrystellingsinhiberende hormone genoem te word. Dit was ook bekend as inhiberingsfaktore.

dosente en afgestudeerdes van die Fakulteit van Geneeskunde van die Universiteit van Pretoria gebruik. Die vraag is nou of die $e$ van die stamwoord behou moet bly en of dit soos die $h$ ook maar kan verval. Tiroïed word immers makliker as tireoied uitgespreek.

Dit sal baie waardeer word as kollegas ander probleemwoorde sal aanteken en aanstuur. Kommentaar op hierdie bespreking sal ook verwelkom word. Op dié wyse sal die Afrikaanse veeartsenykundige vaktaal tot almal se bevrediging uitgebou kan word.

\section{VERWYSINGS}

1. Brink, A.J. (1979). Woordeboek van Afrikaanse
Geneeskundeterme (Nasou Bpk., Goodwood).

2. De Jongh, S.J. (1978). Veeartsenykundige Woordeboek (Staatsdrukker, Pretoria).

3. Karlson, P., Acher, R.A., Boissonnas, R.A., Dixon, H.B.F. Guillemin, R., Rasmussen, H., Rudinger, J. \& Yudayev, N.A. (1974). The nomenclature of peptide hormones, J. Biol. Chem., 250, 3215-3216.

4. Louw, D.F. (1985). Skryfprobleme met chemieterme, S. Afr. Tydskr. Natuurwetenskap en Tegnologie, 4, 80-83.

5. Meyer, B.J. 1983. Die fisiologiese basis van Geneeskunde, 3de uitg. (HAUM, Pretoria).

6. Mish, F.C., Gilman, E.W., Lowe, J.G., McHenry, R.D. \& Pease, R.W. (1983). Webster's Ninth New Collegiate Dictionary (Merriam Webster Inc., Springfield, Massachusetts).

7. Snyman, H.W. (1988). Geneeskundige Woordeboek (Butterworths, Durban). 